\title{
PERIODICITY OF HEIGHT GROWTH IN WHITE SPRUCE REPRODUCTION
}

\author{
By A. K. HELLUM ${ }^{1}$
}

Oxf. 181.65:174.7

\section{ABSTRACT}

$A$ one-year phenological study with white spruce seedlings in central Alberta has shown that seasonal height growth is positively correlated with length of growing period, size of terminal bud, and length of terminal. Bud size is closely related to seedling height but is also affected by factors of the environment and genetic variability among seedlings.

\section{RESUME}

Voici la conclusion d'une étude phénologique des semis d'Epinette blanche (Picea glauca (Moench) Voss) effectuée en Alberta central: plus le bourgeon terminal de la tige est gros, plus la pousse subséquente est longue et plus la période de croissance est, elle aussi, longue. La grosseur du bourgeon varie selon la hauteur du semis mais elle est aussi réglée par les facteurs du milieu et génétiques.

\section{INTRODUCTION}

The phenology of terminal leader growth in young and healthy white spruce (Picea glauca (Moench) Voss) was recorded in 1965 near Chisholm $\left(54^{\circ} 55^{\prime} \mathrm{N}, 114^{\circ} 10^{\prime} \mathrm{W}\right)$, Alberta. It is discussed in its relation to seedling height, terminal bud diameter, and forest shade. Phenology has been discussed for many forest tree species (Berger-Landefeldt and Busch, 1951; Daubenmire, 1949; Fraser, 1966; Friesner, 1943; Kienholz, 1934; Leibundgut and Kunz, 1952; Mork, 1941; Tryon and Finn, 1937) but mature trees rather than seedlings have been studied. Buds of variable size probably affect terminal height growth in mature trees and seedlings alike, but such information is not available, at least for white spruce. If such bud size can be used as an index of subsequent leader extension in seedlings, nursery stock might be graded by bud size.

Leader length is primarily a function of bud diameter (Hanover, 1963) and seedling height and it is secondarily influenced by the environment. Such factors as light intensity. (Fraser, 1966; Skoklefald, 1965), temperatures (Kramer and Kozlowski, 1960), and photoperiod (Wareing, 1949), to name only a few, influence periodicity of height growth, but they are of minor importance under local conditions. Site influences in general have been discussed here under the category of "shade."

\section{METHODS}

Four similarly flat sites, approximately 5 acres in size and about 4 miles apart, were chosen on tills (moisture regime 6-7; Hills and Pierpoint, 1960)

\footnotetext{
${ }^{1}$ Research Scientist, Department of Forestry and Rural Development, Forest Research Labora-
} tory, Calgary, Alberta. 
which remained moist throughout the 1965 growing season. One site is devoid of forest cover while the others have light, medium, and heavy shade supporting 70, 110, and $130 \mathrm{ft}^{2}$ Basal Area/acre respectively. No other measures of shade were taken. Trembling aspen (Populus tremuloides (Michx.)) predominates on all shaded sites with mixtures of white spruce and balsam poplar (Populus balsamifera L.) in the overstory, the latter two species comprising less than $20 \%$ of the total basal area on any, site. All stands developed after logging and fires 10 or more years ago.

The region is frost free for approximately 100 days each growing season. ${ }^{2}$ Maximum temperatures in the open area rose to $82^{\circ} \mathrm{F}$ on warmest days and dropped frequently to $50^{\circ} \mathrm{F}$ on clear nights throughout the summer. Occasional light night frosts were recorded in late May, in June, and in late August.

Terminal growth was recorded weekly from May 13 through August 16 on 93 wild spruce seedlings ranging in age from 2 to 26 years and in height from 2 to $400 \mathrm{~cm}$. It was intended to use 30 seedlings per site. The occurrence of bud midge (Cecidomyidae) reduced this number to 26 under medium shade and to only 7 under heavy shade. The other two sites were not affected by the bud midge.

Times of bud flushing and set were noted for each seedling. Growth was measured with a micrometer to the nearest $0.1 \mathrm{~mm}$.

\section{RESUlTS AND Discussion}

It is generally true that seedlings increase their annual height growth as they grow taller. It is also true, according to this study, that the taller the seedling the later it sets bud in summer or early fall (Figure 1). This is directly related to bud size and to the environment as will be shown subsequently. These relationships are described for seedlings between 20 and $400 \mathrm{~cm}$. tall.

On the average a seedling which grew in height for 30 days produced a leader $10 \mathrm{~mm}$. long (Figure 1) while one that grew for 60 days produced a leader $296 \mathrm{~mm}$. long. The long leader grew nearly 15 times faster and almost 30 times more than the short leader.

A multiple regression between the data on leader length and the interdependent variables of bud diameter and seedling height revealed that primordial bud size exerted a greater influence over terminal leader length than did seedling height ( $\mathrm{R}^{2}$ 's of 0.8770 and 0.8228 respectively). The combined influence of bud diameter (Figure 2) and seedling height (Figure 3) on the leader growth has an $\mathrm{R}^{2}$ value of 0.9162 . As a seedling grows taller, therefore, it produces increasingly larger buds which in turn are capable of producing subsequently longer leaders.

Other factors being equal, a small primordial bud will produce a smaller leader than a larger bud. On the average, a bud $3 \mathrm{~mm}$. in diameter

\footnotetext{
'LINDSAY, D., Unpublished data. Alberta Research Council, Soil Survey Section, Edmonton, Alberta.
} 


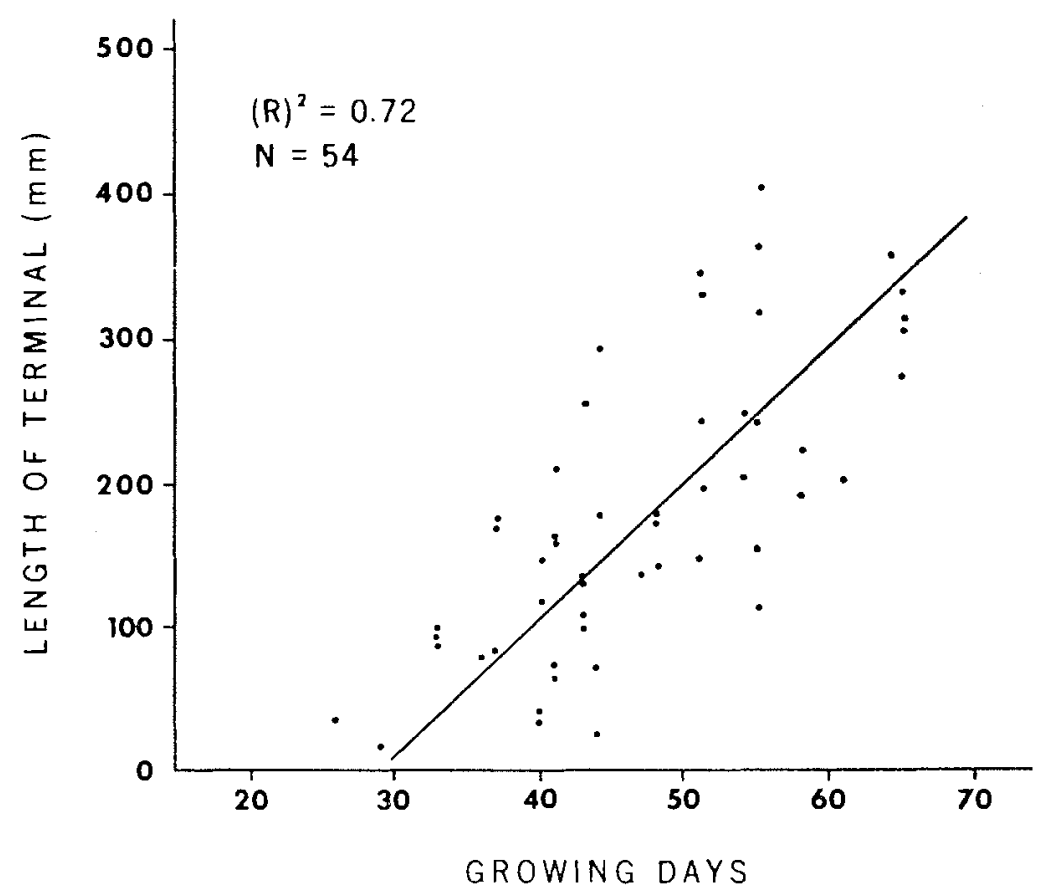

FIGURE 1. The relationship between terminal length and the time required to complete it in white spruce trees 20 to $400 \mathrm{~cm}$. tall.

produced a leader $50 \mathrm{~mm}$. long while one $7 \mathrm{~mm}$. wide produced a leader $300 \mathrm{~mm}$. long. No buds wider than $9 \mathrm{~mm}$. were measured and the relationship between terminal growth and bud diameter was parabolic rather than linear for seedlings less than $400 \mathrm{~cm}$. tall. The bud form in white spruce is variable and this accounts for much of the point scatter shown in Figures 2 and 3.

Terminal leader buds flushed between May 26 and June 6 in all measured individuals. Seedlings less than $40 \mathrm{~cm}$. ended leader growth by the end of June while seedlings taller than $250 \mathrm{~cm}$. grew till August.

Both genetic variability and site influences probably cause much of the variation in periodicity of terminal growth within all measured seedlings. In addition, it has been suggested that seedlings produce larger buds and longer leaders in the open than under forest shade (Rowe, 1961; Skokletald, 1965). The data for seedlings $40-90 \mathrm{~cm}$. tall (Figure 4) support this in view of the fact that the four sites were similar in moisture and topography. The data for this figure are supported by similar data for different height classes of seedlings between 20 and $400 \mathrm{~cm}$. 


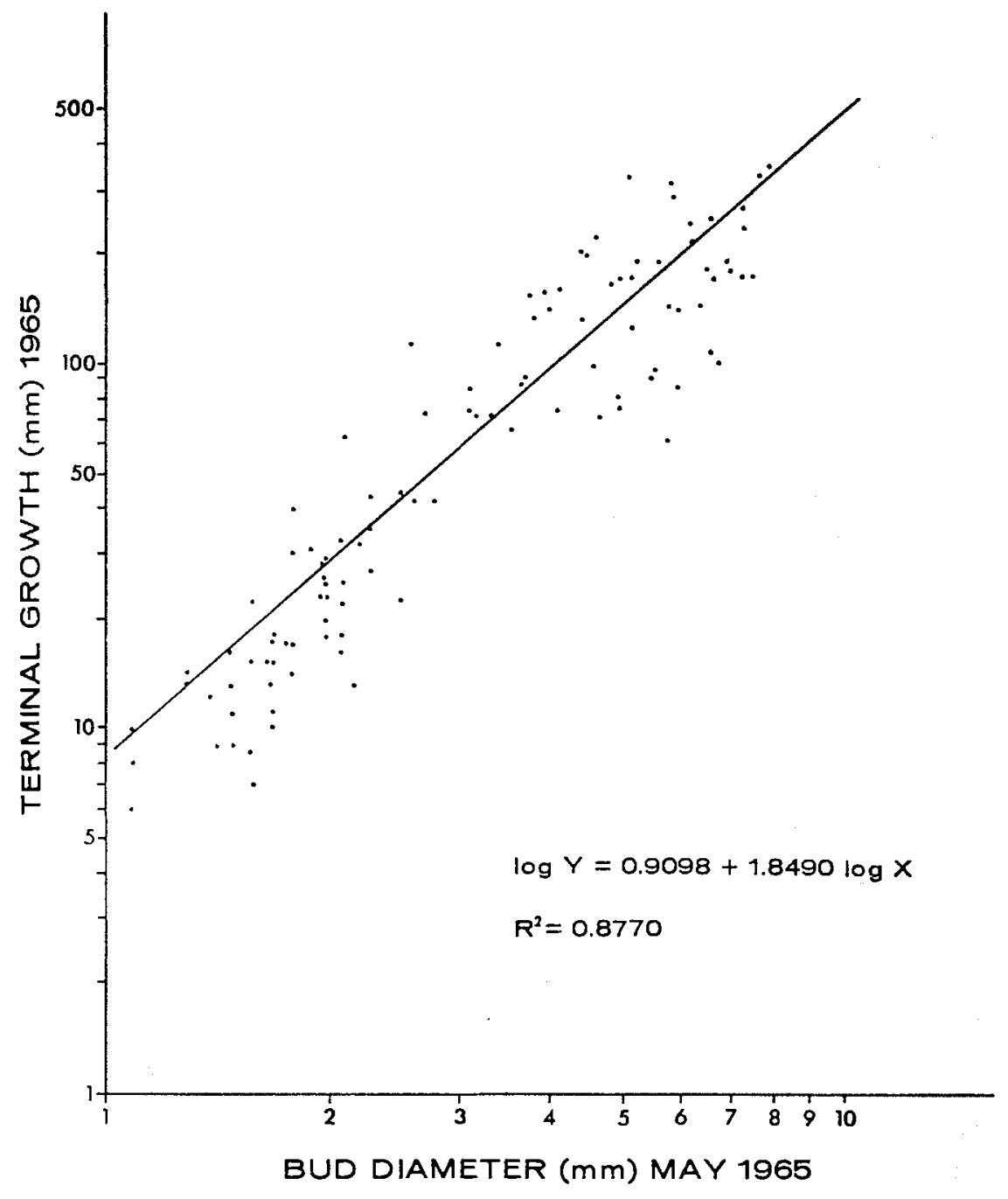

FIGURE 2. The relationship between bud diameter and terminal leader growth in white spruce regeneration 20 to $400 \mathrm{~cm}$. tall. 


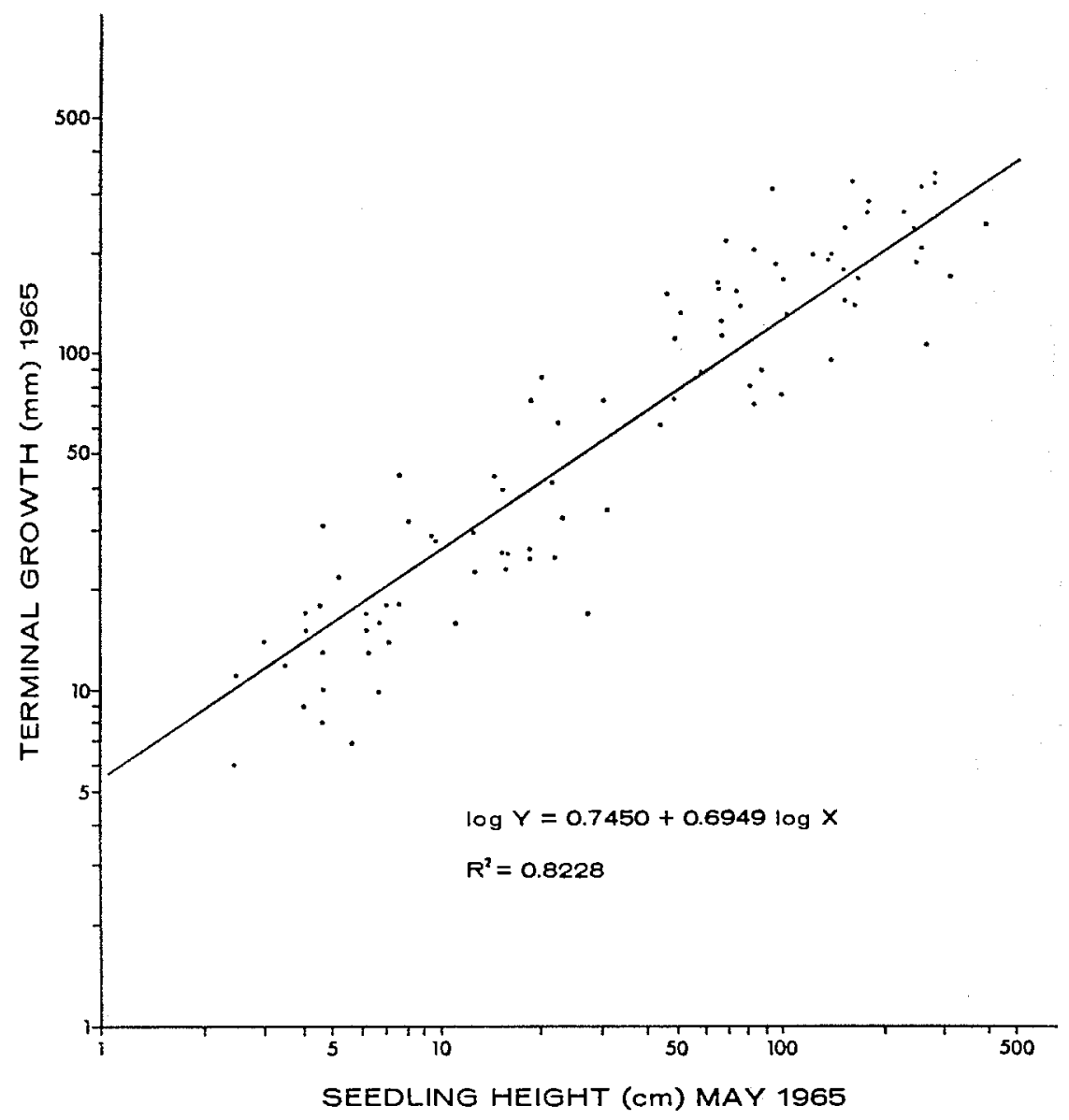

FIGURE 3. The relationship between seedling height and subsequent terminal growth in white spruce trees 20 to $400 \mathrm{~cm}$. tall.

\section{CONCLUSIONS}

Terminal leaders of different lengths develop in different intervals of time in white spruce as in Norway spruce (Picea abies L. Karst.) (Oksbjerg, 1954). All seedlings completed height growth in 65 days or less after beginning growth in late May or early June. Seedlings in this particular year therefore used less than $66 \%$ of the average frost free season for height growth in this part of Alberta. This may explain why Walters and Soos (1963) could not find any relationship between total number of days in the growing season and leader growth in some British Columbia conifers. 


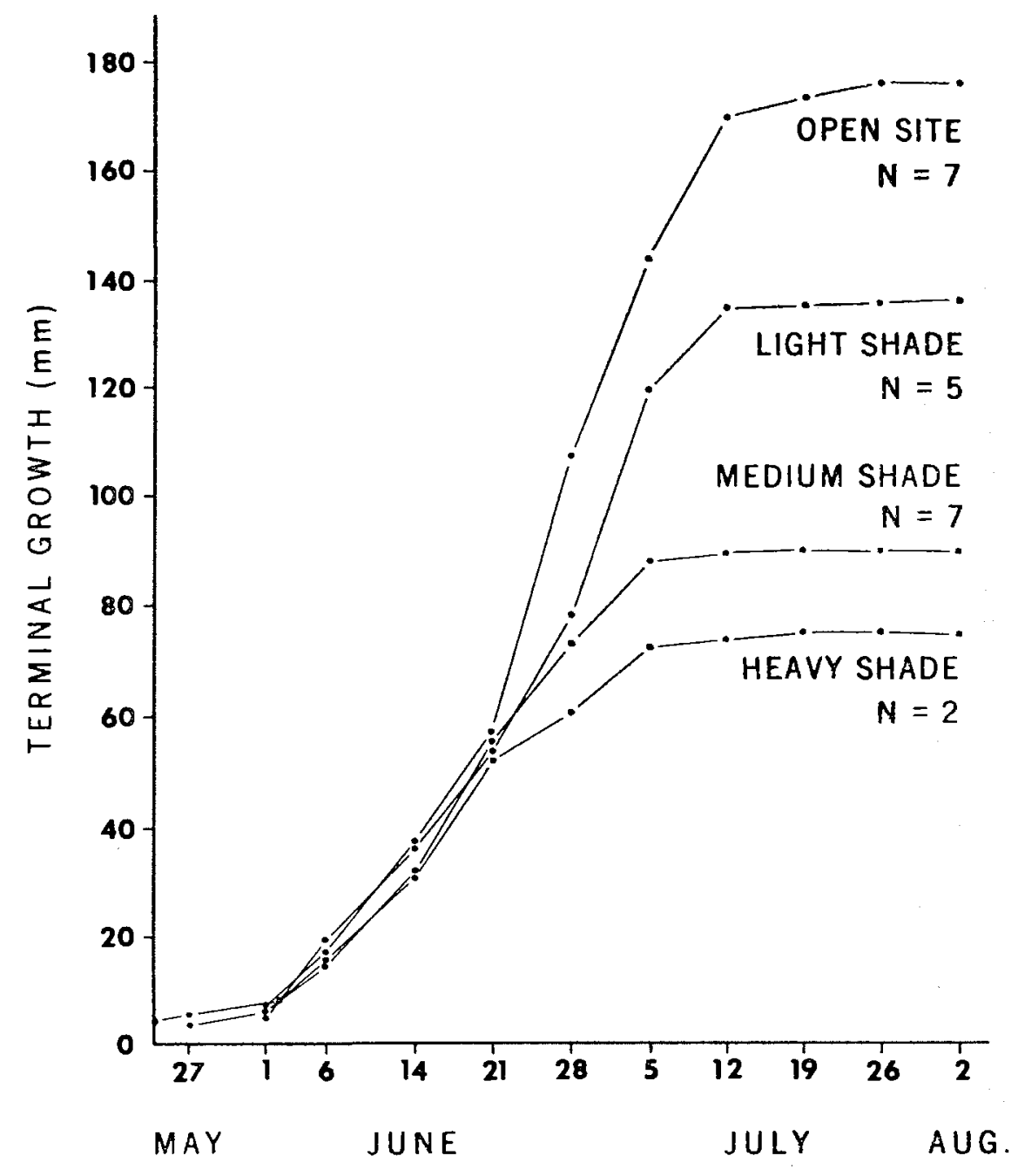

FIGURE 4. Influence of shade on terminal growth in white spruce trees 40 to $90 \mathrm{~cm}$ tall. All four sites were similar except for degree of shade.

The ecological implications of these observations are considerable. While seedling height has a definite influence on the size of terminal bud, its influence on size of leader produced by that bud is tempered by site at the time of bud set and during leader growth. The relative influence of site increases from period of bud formation to period of leader extension because the former is completed in less than a month and the latter takes 
one full growing season. Seedlings which set bud in late June or early July may do so under very different climatic conditions than those which set bud in late July or early August.

Most of the variation observed in leader growth in the 93 sample trees during 1965 has been accounted for by measuring seedling heights and bud diameters. Variations in seedling growth related to genetic variability and to site differences played a minor role, therefore, in the formation of terminal buds and in subsequent height growth under the given sampling conditions.

Based on these results, it should be a simple matter to sort nursery stock according to bud diameter prior to shipment to the field for planting.

\section{Literature Cited}

BERGER-LANDEFELDT, U. and D. BUSCH. 1951. Phaenerometrische Beobachtungen 1951. [Phenological observations] Deutsch. Bot. Gesell. 64:151-155. [Ge.]

DAUBENMIRE, R. F. 1949. Relation of temperature and day length to the inception of tree growth in spring. Bot. Gaz. 110:464-475.

FRASER, D. A. 1966. Vegetative and reproductive growth of black spruce (Pices mariana (Mill.) B.S.P.) at Chalk River, Ontario, Canada. Can. Jour. Bot. 44:567-580.

FRIESNER, R. C. 1943. Correlation of elongation in primary, secondary, and tertiary axes of Pinus strobus and P. resinosa. Butler Univ. Bot. Stud. 6:1-9.

HANOVER, J. W. 1963. Geographic variation in Ponderosa pine leader growth. For. Sci. $9(1): 86-95$.

HILLS, G. A. and G. PIERPOINT. 1960. Forest site evaluation in Ontario. Ont. Dept. of Lands and Forests. Res. Br. Rep. No. 42, 63 pp.

KIENHOLZ. R. 1934. Leader, needle, cambial, and root growth of certain conifers and their inter relations. Bot. Gaz, 96:73-92.

KRAMER, P. J. and T. T. KOZLOWSKI. 1960. Physiology of trees. McGraw Hill Co., N.Y. $642 \mathrm{pp}$.

LEIBUNDGUT, H. and R. KUNZ. 1952. Zur Phänologie der Laubbäume, insbesondere der Buche. [On the phenology of deciduous trees, with emphasis on the beech] Schweitz. Z. f. Forst. 103:29-46. [Ge.]

MORK, E. 1941. Om sambandet mellom temperatur of vekst. (Relationships between temperature and growth) Medd. Det Norske Skogforsöksvesen, 27:1-89. [Nor., ge.]

OKSBJERG, E. 1954. Om udspridnigstid og skudstraekning $\mathrm{i}$ grankulturer. [Bud burst and shoot length in spruce provenances] Hedeselsk. Tidskr. 75:49-55. [Da.]

RICHARDSON, J. 1965. Phenological observations at North Pond Experimental Area. Progress Rep. NF-77. Canada Dept. of Forestry, For. Res. Branch. 15 pp. mimeo.

ROWE, J. S. 1961. Survival of white spruce seedlings, Riding Mountain. (Unpubl. M.S. No. 150) Dept. of Forestry, Sask.-Manitoba region.

SKOKLEFALD, S. 1965. Forsök med ulike spireleiebehandlinger $\mathrm{i}$ samband med direkte saaing av gran- og furufrö. [Experiments with various seedbed treatments in connection with direct seeding of Norway spruce and Scots pine] Medd. Det Norske Skogforsöksvesen 20 (4):209-247. [Nor., eng.]

TRYON, H. H. and R. F. FINN, 1937. Notes on the terminal growth of coniferous plantations in the Hudson highlands. Black Rock Forest Papers 1:54-56.

WALTERS, J. and J. SOOS, 1963. Shoot growth patterns in some British Columbia conifers. For. Sci. $9(1): 73-85$.

WAREING, P. F. 1949. Photoperiodism in woody species. Forestry 22(2):211-221. 